\title{
5
}

УДК 576.355

\section{A NEW TOXIC PROTEIN FROM DEATH CAP AMANITA PHALLOIDES: ISOLATION AND STUDY OF CYTOTOXIC ACTIVITY}

\author{
Taras Stasyk ${ }^{1,4}$, Maxim Lootsik, Ulf Hellman², Christer Wernstedt ${ }^{2}$, \\ Serhiy Souchelnytskyi ${ }^{3}$, Rostyslav Stoika ${ }^{{ }^{*}}$ \\ 'Institute of Cell Biology, NAS of Ukraine, 79005 Lviv, Ukraine \\ ${ }^{2}$ Ludwig Institute for Cancer Research, Box 595, SE-751 24, Uppsala, Sweden \\ ${ }^{3}$ Karolinska Biomics Center, Karolinska Institutet, SE-171 76, Stockholm, Sweden \\ ${ }^{4}$ Biocenter, Innsbruck Medical University, A-6020, Innsbruck, Austria \\ "To whom correspondence should be addressed
}

Cytotoxic protein from fruit body of the death cap Amanita phalloides mushroom, designated as toxophallin, has been isolated and its principal physico-chemical and biological properties have been characterized. This protein possesses molecular mass $55 \mathrm{kDa}$ and isoelectric point at pH 5.7 and is expressed predominantly in the stem of mushroom fruit body. As assessed by cross-linking experiments, toxophallin forms a trimeric complex in buffered solution. It induces apoptosis in several mammalian cells lines (murine L1210 and CCL-64, and human A549) with $\mathrm{IC}_{50}$ at $0.25-0.45 \mu \mathrm{g} / \mathrm{ml}$. It also induces DNA fragmentation and morphological changes in the nuclei of target cells (chromatin condensation and fragmentation of nuclei) that are characteristic for apoptosis. Caspase III Inhibitor (Boc-D-fmk) does not inhibit toxophallin-induced apoptotic DNA fragmentation, suggesting that this toxin involves caspase-independent pathway of apoptosis. Besides, it was shown that toxophallin interaction with target cells is not mediated by specific cell surface receptor. Thus, toxophallin is a new toxic protein whose properties distinguish it from other toxic compounds (cyclopeptides and phallolysin) earlier found in the death cap.

Key words: toxic protein, death cap Amanita phalloides, apoptosis.

The abbreviations used in the article:

Boc-D-fmk, Benzyloxycarbonyl-Asp-Ome-fluoromethylketone, Caspase Inhibitor III;

DAPI, 4,6-diamidino-2-phenylindole;

DMEM, Dulbecco's modified Eagle's medium;

PBS, phosphate-buffered saline;

TUNEL, terminal deoxynucleotidyl-transferase (TdT) mediated dUTP-biotin nick end labeling. 


\title{
НОВИЙ ТОКСИЧНИЙ БІЛОК ІЗ БЛІДОЇ ПОГАНКИ АMANITA PHALLOIDES L.: ОЧИСТКА ТА ДОСЛІДЖЕННЯ ЦИТОТОКСИЧНОЇ АКТИВНОСТІ
}

\author{
Т. Стасик ${ }^{1,4}$, М. Луцик', У. Гельман ${ }^{2}$, К. Вернстедт ${ }^{2}$, \\ С. Сушельницький ${ }^{3}$, Р. Стойка ${ }^{1^{*}}$ \\ 'Інститут біології клітини, НАН України, 79005 Львів, Україна \\ 2Людвігівський інститут досліджень раку, а/с 595, SE-751 24, Уппсала, Швеція \\ ${ }^{3}$ Каролінський центр біоміки, Каролінський Інститут, SE-171 76, Стокгольм, Швеція \\ ${ }^{4}$ Біоцентр, Медичний університет Інсбруку, А-6020, Інсбрук, Австрія \\ "Кому скеровувати кореспонденцію
}

Із фруктового тіла гриба блідої поганки Amanita phalloides L. очищено токсичний білок, названий токсофаліном. Описано його основні фізико-хімічні та біологічні властивості. Цей білок має молекулярну масу 55 кДа й ізоелектричну точку при pH 5.7. Він зосереджений переважно в основі фруктового тіла гриба. Експерименти із поперечною зшивкою білкових молекул продемонстрували, що токсофалін утворює тримерний комплекс у буферному розчині. Він індукує апоптоз у ряді ліній клітин ссавців (мишачі клітини ліній L1210 і CCL-64, а також людські клітини лінії A549) із $\mathrm{IC}_{50}$ при 0.25-0.45 мкг/мл. Він також індукує фрагментацію ДНК та морфологічні зміни в ядрі клітин-мішеней (конденсацію хроматину і фрагментацію ядра), що характерно для апоптозу. Інгібітор каспази III (Boc-D-fmk) не пригнічував апоптичної фрагментації ДНК, що дає змогу припустити, що цей токсин залучає в дію каспазо-незалежний шлях апоптозу. Крім того, виявлено, що взаємодія токсофаліну з клітинами-мішенями не опосередковується специфічними рецепторами на поверхні цих клітин. Отже, встановлено, що токсофалін $є$ новим токсичним білком, властивості якого відрізняють його від інших токсичних сполук (циклопептиди і фалолізин), знайдених раніше у блідій поганці.

Ключові слова: токсичний білок, бліда поганка Amanita phalloides, апоптоз.

\section{INTRODUCTION}

Death cap (Amanita phalloides L.) is known as a deadly poisonous mushroom due to the presence of several toxic substances. First of them was isolated in 1937 by Wieland H. (see: [1]) and identified as oligopeptide. In further works, Wieland Th. revealed other toxic cyclopeptides which were classified into two structural groups amanitine and phalloidine, exhibiting different mechanisms of toxic action [21]. While amanitin is blocking mRNA transcription, phalloidin binds to actin and alters cytoskeleton functions. These cyclopeptides are frequently used as tools in scientific studies since their intracellular molecular targets and mechanisms of action are well characterized. It should be noted that besides toxic peptides this mushroom also contains antitoxin antamanide, a cyclodecapeptide which blocks phalloidin effects [1, 21]. Later on, another toxic polypeptide substance, phallolysin, possessing hemolytic activity was detected in the fruit bodies of the death cap [4, 5, 16-18]. Its chemical properties and biological activity, as well as the mechanism of action, are well studied $[8,21]$. 
Many mushroom species were shown to contain substances that possess immunomodulating and antitumor activity $[3,9,13]$. Lectin-like proteins demonstrating antiproliferative activity towards tumor cells were isolated from Tricholoma mongolicum [20] and Agaricus bisporus [15] mushrooms. Another antineoplastic protein, volvarin, that belongs to the family of ribosome inactivating proteins (RIP) type I, was isolated from edible mushroom Volvariella volvacea [22]. Poisonous mushroom Boletus satanas Lenz contains a toxic lectin bolesatine which inhibits protein synthesis in vitro and in vivo [10].

In the present work, we have characterized a novel protein isolated from fruit bodies of the death cap. An improved procedure for purification of this protein has been described. Detailed investigation of its action towards several lines of tumor cells was carried out. Its physico-chemical and biological properties clearly distinguish this novel cytotoxic protein from phallolysin [12].

\section{MATERIALS AND METHODS}

\section{Isolation and Purification of Cytotoxic Proteins from the Death Cap}

Fruit bodies of Amanita phalloides mushrooms were collected in the forests of the Lviv Region (Ukraine), and stored at $-20^{\circ} \mathrm{C}$ until use (no longer than 2 weeks). Thawed mushrooms were pressed, subjected to centrifugation for $15 \mathrm{~min}$ at $4,000 \mathrm{~g}$, and the supernatant was collected. Ammonium sulfate was added to the supernatant to $90 \%$ saturation, and precipitated proteins were collected by filtration. For elimination of dark colored pigment, the precipitate was dissolved in a small volume of distilled water, dialyzed against buffer solution ( $50 \mathrm{mM}$ potassium phosphate buffer, $\mathrm{pH} 7.0$ supplemented with $100 \mathrm{mM}$ sodium chloride), and passed through a DEAE-cellulose column (Serva), equilibrated with the same buffer. The fraction of unabsorbed protein was collected and precipitated with ammonium sulfate at $90 \%$ saturation.

For elimination of cytolytic lectin, phallolysin, the crude protein fraction was passed through a column filled with affinity sorbent - ovomucin immobilized on agarose [2], that was equilibrated with PBS. Unbound „non-lectin” protein fraction was collected, dialyzed against $30 \mathrm{mM}$ sodium acetate buffer ( $\mathrm{pH} 5.3)$, and applied onto a CM-cellulose column (Whatman, CM-32), equilibrated with $30 \mathrm{mM}$ sodium acetate buffer, $\mathrm{pH}$ 5.3. The absorbed protein material was eluted in two steps: first with $100 \mathrm{mM}$ sodium acetate buffer, and subsequently with the same buffer supplemented with $75 \mathrm{mM}$ sodium chloride. Protein possessing cytotoxic activity was eluted with $100 \mathrm{mM}$ sodium acetate buffer, $\mathrm{pH} 5.3$, containing $75 \mathrm{mM}$ sodium chloride. This protein peak was collected, concentrated, and subjected to re-chromatography on the CM-cellulose column in $100 \mathrm{mM}$ sodium acetate buffer, $\mathrm{pH}$ 5.3, with $75 \mathrm{mM}$ sodium chloride. The main protein peak corresponding to pure cytotoxic protein, was collected, dialyzed against distilled water, and lyophylized.

\section{Electrophoretic Study}

Two electrophoretic systems were used for protein characteristics: 1) discelectrophoresis in $7.5 \%$ polyacrylamide gel (PAGE) using the Reisfeld system in $\beta$-alanine-acetate buffer, $\mathrm{pH} 4.5$ and protein staining with Amido Black $10 \mathrm{~B}$ [14], and 2) SDS-PAGE in 14\% slab gel in Laemmli buffer system [11] and followed by protein visualization using Coomassie Brilliant Blue R 250. Protein markers of molecular mass were ranged from 14.4 to $94 \mathrm{kDa}$ (GE Healthcare). 


\section{Isoelectric Point (pl) Determination}

Analytical isoelectric focusing was performed on Immobiline DryStrip pH 3-10, $18 \mathrm{~cm}$, linear (Amersham Pharmacia Biotech, Uppsala, Sweden) in IPGphor (GE Healthcare, Uppsala, Sweden) according to the manufacturer's recommendations. After resolution in the second dimension by SDS-PAGE in $10 \%$ gel, proteins were visualized by silver staining and pl was determined according to the manufacturer's instructions.

\section{Cells}

Human lung carcinoma epithelial A549 cells, mink lung epithelial CCL-64 cells, human breast adenocarcinoma MCF-7 and T47D cells, and murine leukemia L1210 cells were obtained from American Type Culture Collection (Manassas, USA). Cells were cultured in DMEM (Life Technologies, Inc.) supplemented with $10 \%$ fetal bovine serum (FBS), 100 units $/ \mathrm{ml}$ of penicillin, and $50 \mu \mathrm{g} / \mathrm{ml}$ of streptomycin.

\section{Toxophallin lodination and Cross-linking}

Toxophallin was iodinated using Chloramine-T method, as described by Frolik et al. [7], and cross-linking with $\mathrm{BS}^{3}$ (Bis(sulfosuccinimidyl)suberate, Pierce) was performed, as described in [6]. The binding experiments were performed at $4^{\circ} \mathrm{C}$ to avoid potential internalization of the bound protein.

\section{$\left[{ }^{3} \mathrm{H}\right]$-Thymidine Incorporation Assay}

$\left[{ }^{3} \mathrm{H}\right]$-thymidine incorporation into DNA of target cells grown at different concentrations of toxophallin, was determined as described in [19].

\section{DNA Fragmentation Assay}

Total genomic DNA from treated cells was extracted, as described in [8], and analyzed by electrophoresis in 1\% agarose gel after DNA visualization by the ethidium bromide.

\section{Study of Apoptotic Cells by Fluorescence Microscopy}

Morphology of target cell nucleus and its changes under toxophallin treatment were examined by fluorescence microscopy using an Axioplan 2 microscope (Zeiss, Jena, Germany), after cell staining with DAPI (4,6-diamino-2-phenylindole), as described in [19].

DNA fragmentation in individual cells was studied by TUNEL assay (terminal deoxynucleotidyl-transferase (TdT) mediated dUDP nick end labeling) using In Situ Cell Death Detection Kit, Fluorescein (Boeringer Mannheim), according to the manufacturer's instructions.

\section{Statistical Analysis}

All experiments were repeated at least three times with a minimum of three parallels. Standard deviation was calculated, and statistical significance of difference was evaluated by using Student's t-test $(P<0.05)$.

\section{RESULTS}

\section{Purification of Toxophallin}

The purification procedure consisted of 4 steps: 1 ) ammonium sulfate precipitation of total protein from juice of thawed and grinded mushrooms; 2) elimination of pigment(s) from the obtained protein bulk by ion-exchange chromatography on DEAEcellulose column; 3) affinity chromatography on absorbed immobilized ovomucin for removing cytolytic lectin, phallolysin; 4) purification of toxophallin by repeated ionexchange chromatography on $\mathrm{CM}$-cellulose column. The first three steps were 
essentially the same, as described in [12]. As an additional step, re-chromatography on CM-cellulose column was introduced for achievement of higher grade of toxophallin purification. Described procedure permitted to obtain toxophallin preparation showing more than $95 \%$ purity. Protein yield at sequential purification steps is demonstrated in Table 1. Since it was difficult to compare cytotoxic activity of protein fractions at different steps of purification procedure (Table 1), we can only suggest that fold of toxophallin purification was about 70 .

Table 1. Protein yield during the course of toxophallin purification

\begin{tabular}{c|l|c}
\hline Step & \multicolumn{1}{|c}{ Characteristics of purification stage } & Protein yield, mg \\
\hline 1 & $\begin{array}{l}\text { Protein precipitation of } 500 \mathrm{ml} \text { of juice of death cap fruit } \\
\text { bodies by ammonium sulphate at } 90 \% \text { saturation }\end{array}$ & 650 \\
\hline 2 & Elimination of pigments by DEAE cellulose chromatography & 150 \\
\hline 3 & $\begin{array}{l}\text { Elimination of phallolysin by affinity chromatography on } \\
\text { ovomucin-congugated agarose }\end{array}$ & 110 \\
\hline 4 & lon-exchange chromatography on CM-cellulose & 15 \\
\hline 5 & Re-chromatography on CM-cellulose & 9 \\
\hline
\end{tabular}

Electrophoresis at non-denaturating conditions ( $\mathrm{pH} 4.5)$ of water-soluble protein sample after elimination of pigment revealed 3 main protein bands (Fig. 1). The predominant band corresponds to phallolysin which is known to exhibit high cytolytic activity. Affinity chromatography on immobilized ovomucin sorbent was used for effective removing phallolysin which specifically binds to the ovomucin, while other proteins do not possess such affinity.

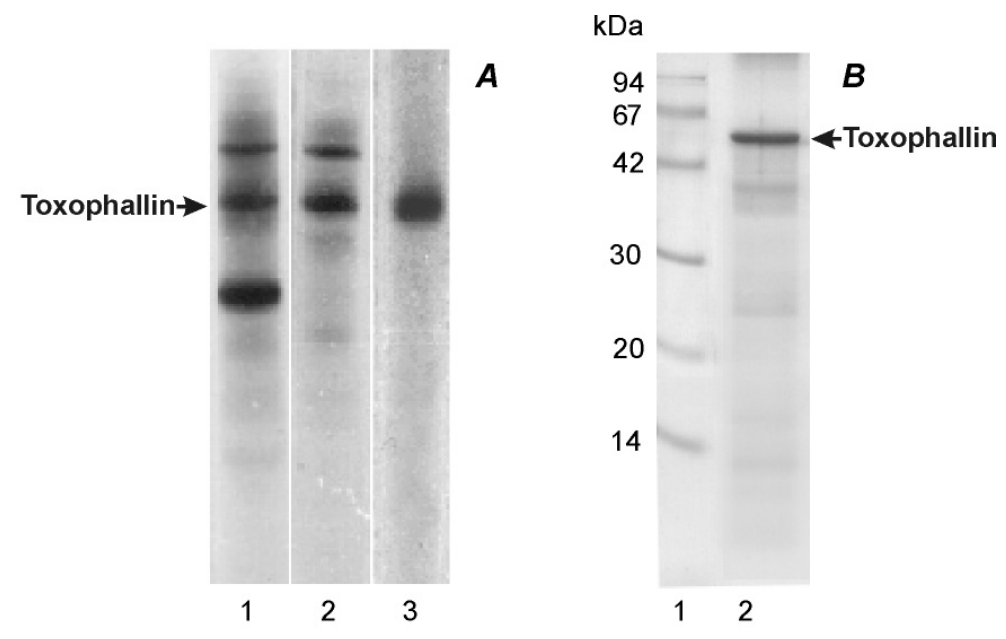

Fig. 1. Electrophoretic study of extracted proteins of Amanita phalloides.

$\boldsymbol{A}$ - $\beta$-alanin-acetate electrophoretic system, $\mathrm{pH} 4.5$ :

1) crude extract; 2) non-lectin proteins (not retained by affinity sorbents); 3) cytotoxic protein purified by ion-exchange chromatography on CM-cellulose column.

$\boldsymbol{B}$ - SDS-PAGE in $14 \%$ gel:

1) molecular mass protein markers (Sigma); 2) purified protein (55 kDa) under study.

Coomassi R-250 staining 
Cytotoxic activity of the obtained fractions was monitored by testing hemolytic and cytotoxic effects towards L1210 leukemia cells in vitro. Only traces of hemolytic activity were found in non-absorbed fraction $(400 \mu \mathrm{g} / \mathrm{ml})$, while the hemolytic activity of pure phallolysin was equal $5 \mu \mathrm{g} / \mathrm{ml}$. Cytotoxic activity was detected not only in phallolysin fraction retained on the column and eluted thereafter, but also in nonretained (non-lectin) fraction.

Protein exhibiting cytotoxic activity found in the non-lectin faction, was further purified by the ion-exchange chromatography and re-chromatography on CM-cellulose column (see: Materials and Methods). Toxophallin was eluted from the column by $100 \mathrm{mM}$ sodium acetate buffer supplemented with $75 \mathrm{mM}$ sodium chloride. Purified toxophallin migrated as a homogenous band at electrophoresis under the nondenaturating conditions (Fig. 1, A). Single protein band of $55 \mathrm{kDa}$ was also detected at SDS-PAGE in the presence or absence of reducing agent (Fig. $1, B$, data not shown). The purity of toxophallin preparation was about $95 \%$ according to the results of electrophoresis in non-denaturating conditions, and about $85 \%$ at SDS-PAGE. We suggest that minor Coomassi-stained bands with the molecular mass below $55 \mathrm{kDa}$ might be products of the proteolytic degradation of the main protein band.

The isoelectric point $(\mathrm{pl}$ ) of purified toxophallin measured by means of 2D-electrophoresis using Immobiline DryStrip pH 3-10, was found to be $\mathrm{pH}$ 5.7.

\section{Amino Acid Composition}

Amino acid analysis showed 3 cysteine, 6 methionine and 36 proline residues in toxophallin molecule that is about $7 \%$ of amino acid residues present in this $55 \mathrm{kDa}$ protein comprising of about 503 amino acid residues (Table 2). Relatively high content of proline residues suggests a significant rigidity of polypeptide chain of the toxophallin.

\section{Biological activity of toxophallin}

Toxophallin possesses cytotoxic activity that was detected by trypan blue exclusion assay in L1210 murine leukemic cells in vitro. $\mathrm{IC}_{50}$ of partially purified toxophallin (non-lectin protein fraction) was equal $0.35 \mu \mathrm{g} / \mathrm{ml}$, while after final purification step that indicator was equal $0.28 \mu \mathrm{g} / \mathrm{ml}$. There was no cytolytic activity in the purified toxophallin preparations (data not shown).

To explore whether toxophallin exhibits a specific effect towards tumor cells as compared to cells obtained from normal tissues, $\left[{ }^{3} \mathrm{H}\right]$-thymidine incorporation assay was applied. It was revealed that toxophallin-induced inhibition of $\left[{ }^{3} \mathrm{H}\right]$-thymidine incorporation by target cells was similar in different cell lines tested (Fig. 2). IC ranged from $0.25 \mu \mathrm{g} / \mathrm{ml}$ in human lung carcinoma cells of A549 line and human breast carcinoma cells of T47D line to $0.45 \mu \mathrm{g} / \mathrm{ml}$ in mink lung epithelial cells of CCL-64 line and human breast carcinoma cells of MCF-7 line.

In order to investigate toxophallin influence on cell proliferation, we performed luciferase assay with E2F reporters, which reflects activation of gene involved in cell cycle regulation. The obtained results permit one to suggest that toxophallin has no effect upon cell cycling (data not shown).

Taking into account that $\mathrm{IC}_{50}$ values in cell viability test estimated by trypan blue exclusion assay $(0.28 \mu \mathrm{g} / \mathrm{ml})$ as well as in cell proliferation tested by $\left[{ }^{3} \mathrm{H}\right]$-thymidine incorporation assay $(0.25-0.45 \mu \mathrm{g} / \mathrm{ml})$ were of the same range, it might be supposed that toxophallin possesses rather cytotoxic than antiproliferative activity.

As postulated by P. Ehrlich „Corpora non agunt nisi fixata”, the first step in the molecular mechanisms of biological action of any agent upon target cell is its binding 
Table 2. Amino acid composition of the $55 \mathrm{kDa}$ cytotoxic protein from A. phalloides fruit bodies

Composition is reported as number of residues per mole of protein based on molecular weight of $55 \mathrm{kDa}$ (SDS-PAGE). The value for tryptophan was not determined (nd), but approximately calculated basing on absorption characteristics of chromatography fractions (ratio A254/A280) and mass-spectrometry data $\left(^{*}\right)$.

\begin{tabular}{c|c|c}
\hline $\begin{array}{c}\text { Amino acid } \\
\text { residue }\end{array}$ & Mol \% & $\begin{array}{c}\text { Residues per } \\
\text { mol of protein } \\
\text { (calculated) }\end{array}$ \\
\hline Asx & 12.1 & 59 \\
Thr & 7.3 & 40 \\
Ser & 7.0 & 34 \\
Glx & 8.1 & 39 \\
Pro & 7.4 & 36 \\
Gly & 8.2 & 40 \\
Ala & 7.5 & 37 \\
Cys & 0.6 & 3 \\
Val & 7.3 & 36 \\
Met & 1.2 & 6 \\
Ile & 6.5 & 32 \\
Leu & 7.2 & 35 \\
Tyr & 3.4 & 17 \\
Phe & 3.9 & 19 \\
His & 3.4 & 17 \\
Lys & 5.9 & 29 \\
Arg & 2.9 & 14 \\
Trp & ND & $(10)^{\star}$ \\
\hline Total & 100 & $503 \mathrm{aa}$ \\
& & $55,153 \mathrm{Da}$ \\
\hline
\end{tabular}

with cell surface receptor. In order to identify specific toxophallin binding proteins in plasma membrane of target cells, toxophallin was labeled with ${ }^{125}$ I, and then cross-linking technique was used. Experiments using two cross-linkers, DSS and $\mathrm{BS}^{3}$ (membrane impermeable water soluble DSS analogue), did not show specific surface receptor on cells of different lines (A549, CCL-64, MCF-7) in a broad range of cross-linking agent concentrations $(0.008-1.0 \mathrm{mM})$. Protein binding was a non-saturable process and was not affected by the presence of 100 -fold molar excess of non-radioactive protein. Thus, toxophallin interaction with target cells does not seem to be receptor-mediated. In these cross-linking experiments, it was also found that toxophallin is capable of forming trimers in solution. In the presence of very low concentration $(0.04 \mathrm{mM})$ of the cross-linker $\mathrm{BS}^{3}$, toxophallin formed a complex of molecular mass equal $160 \mathrm{kDa}$ (Fig. 3) that corresponded to a trimer of $55 \mathrm{kDa}$ monomers.

A possibility that toxophallin can promote cell death via apoptosis induction was studied by DNA fragmentation assay performed on different cell lines. Genomic DNA of murine leukemia L1210 cells, mink lung epithelial CCL-64 cells, and human lung carcinoma A549 cells was isolated from non-treated or toxophallin treated cells and analyzed by electrophoresis in agarose gel. Non-treated cells did not show DNA fragmentation, while toxophallin-treated cells clearly showed DNA laddering that depended upon toxophallin doze (Fig. 4, A). Toxophallin induced DNA fragmentation at concentrations as low as $0.12 \mu \mathrm{g} / \mathrm{ml}$. In case of CCL-64 and A549 cells, DNA fragmentation was not that distinct, as it was in the case of L1210 cells treated with toxophallin (Fig. 4, B). Thus, we demonstrated that target cells of different species and tissue origin undergo apoptosis under toxophallin action.

To explore the molecular mechanisms of pro-apoptotic action of toxophallin, we have studied involvement of caspases in toxophallin action. It was found that pretreatment of $\mathrm{L} 1210$ cells for $2 \mathrm{~h}$ before toxophallin addition with $25 \mathrm{mM}$ caspase inhibitor III (Boc-D-fmk), cell-permeable irreversible caspase inhibitor, did not affect toxophallin dependent apoptotic fragmentation of the DNA. In another experiment, 


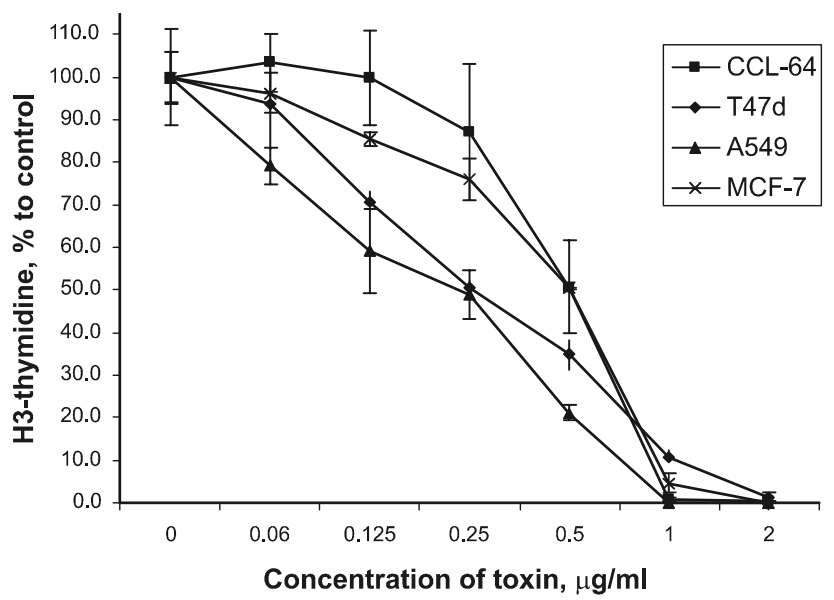

Fig. 2. Dose-dependence of toxophallin effect towards DNA synthesis in different target cells.

Cell lines are noted in the box in the upper right side of the figure. Radioactivity of ${ }^{3} \mathrm{H}$-thymidynelabeled trichloroacetic acid-insoluble polymers was measured in scintillation beta-counter

pre-treatment of A549 cells with Boc-D-fmk had no effect on toxophallin-induced inhibition of thymidine incorporation. Thus, apoptosis induction by toxophallin does not depend on caspase cascade pathway.

Proapoptotic action of toxophallin demonstrated in DNA-laddering assay, was proved by the results of cytomorphological study of cell nucleus using DAPI staining. The most pronounced change in cell morphology after toxophallin treatment was nuclear chromatin condensation (Fig. 5, A). For a part (3$4 \%$ ) of cell population, that process (nucleus condensation) was accompanied by an appearance of apoptotic bodies which are characteristic for cells undergoing apoptosis. DNA fragmentation in the nucleus of cells treated with toxophallin, was also proved by terminal deoxynucleotidyl-transferase (TdT) mediated dUDP nick-end labeling (TUNEL assay (Fig. 5, B). There were no TUNEL-positive cells in population of untreated cells, while the number of TUNEL-positive cells increased significantly in a concentration-dependent manner under toxophallin treatment. It correlated with the number of condensed nuclei observed at DAPI staining. Similar pattern of morphological changes in cell nuclei under toxophallin treatment was observed in various cell lines (A549, MCF-7, CCL-64).

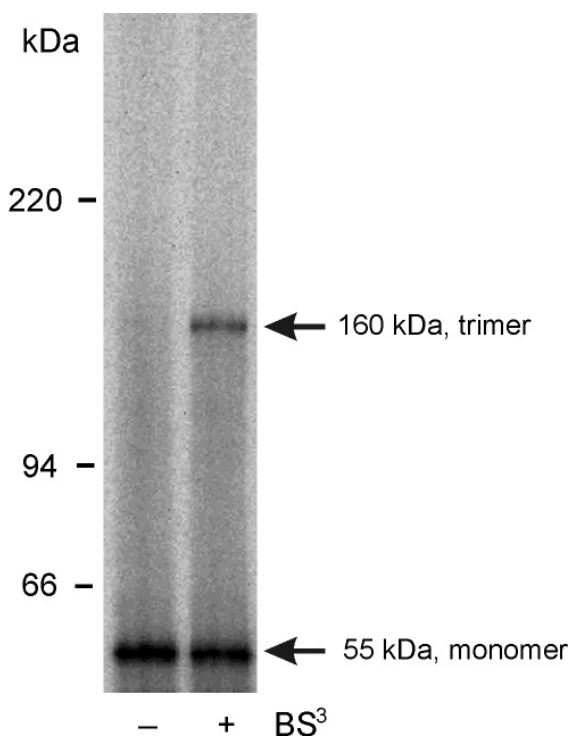

Fig. 3. Electrophoretic study of the products of cross-linking reaction using toxophallin.

Toxophallin was labeled with ${ }^{125}$ and cross-linked with $\mathrm{BS}^{3}(0.04 \mathrm{M}, 15 \mathrm{~min}$ on ice). The products of its crosslinking with membrane proteins of L1210 cells were resolved in 5-7.5\% gradient SDS-PAGE, and exposed in Fuji X 2000 Phospholmager. Arrows show migration of toxophallin as monomer (55 kDa) and trimer (160 kDa). Migration distance of molecular mass protein markers is also shown 


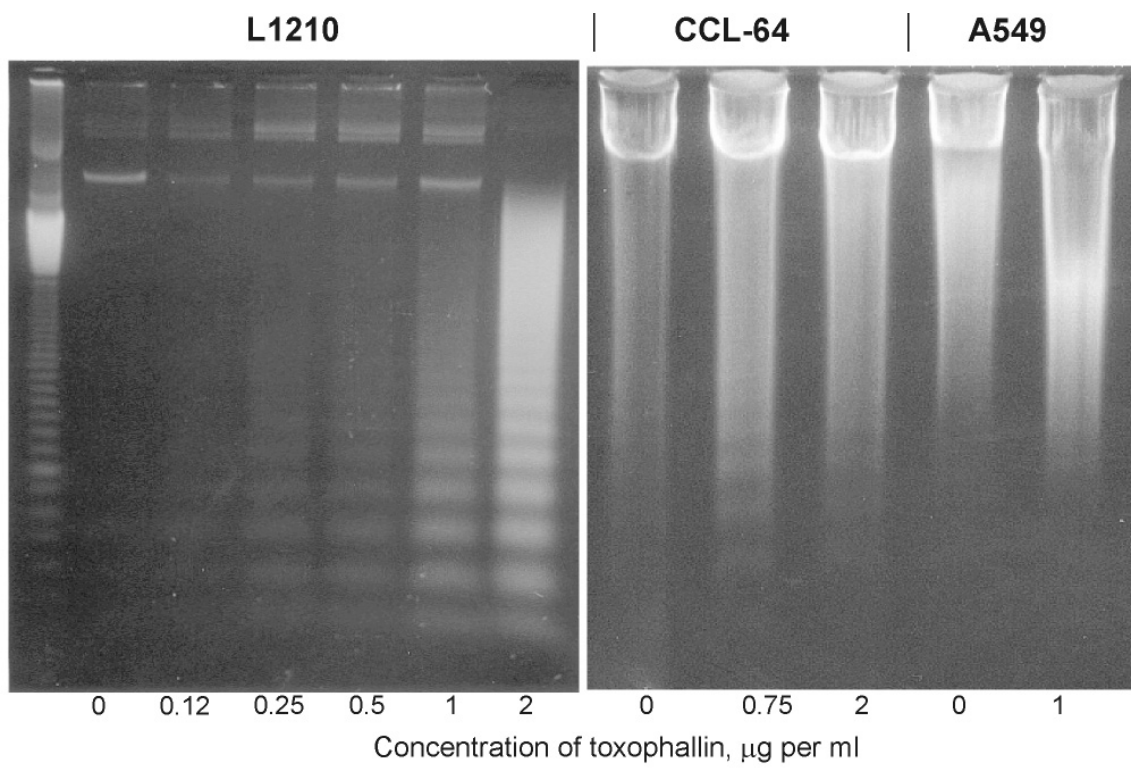

Fig. 4. Electrophoretic study of toxophallin-induced DNA fragmentation in different target cells. Cells were treated for $24 \mathrm{~h}$ with different doses of toxophallin. Total genomic DNA was collected and resolved in $1 \%$ agarose gel

Concentration of toxin, $\mu \mathrm{g}$ per $\mathrm{ml}$

0 (Control)

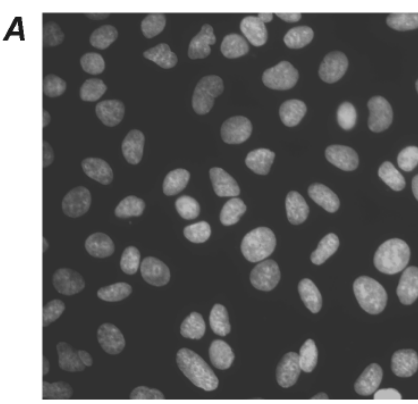

B

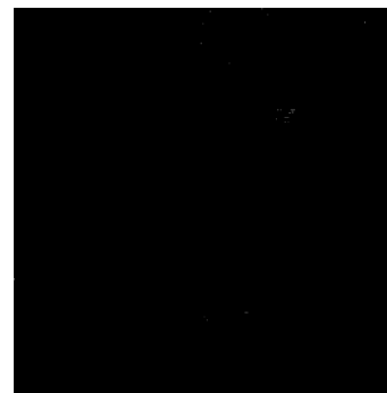

0.5
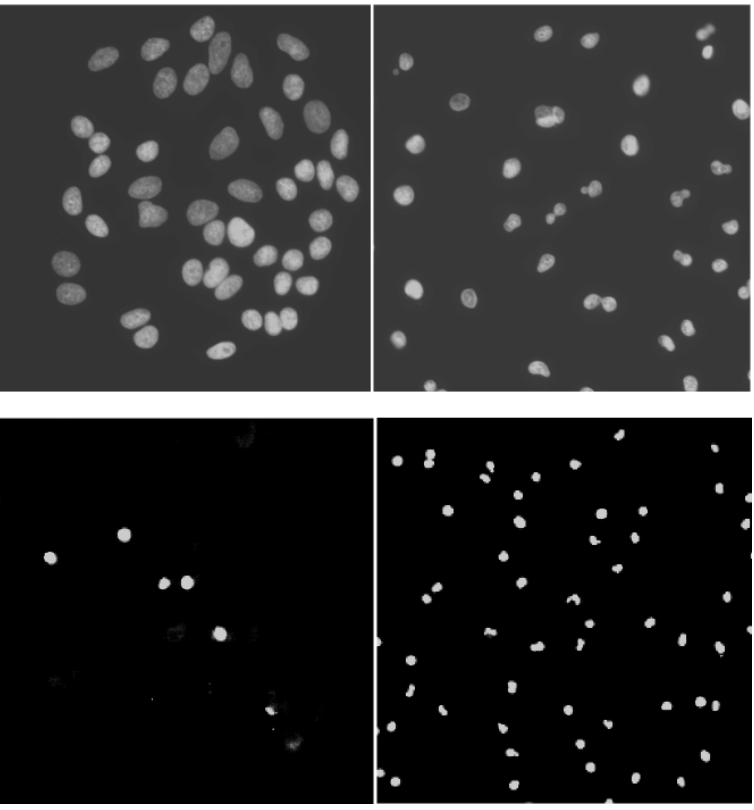

Fig. 5. Fluorescence microscopy of toxophallin-induced nucleus condensation and DNA fragmentation in A549 cells, as evaluated by chromatin staining with DAPI $(A)$ or TUNEL $(B)$. Representative fields of typical experiment out of 3 experiments performed are shown 


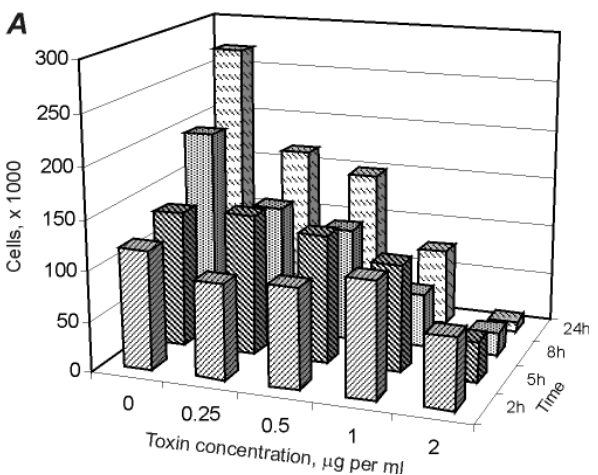

Fig. 6. Toxophallin-induced changes in target A549 cell permeability and nucleus morphology after $5 \mathrm{~h}$ cell treatment. Trypan blue exclusion assay $(A)$ and DAPI staining $(B)$ were performed. Toxophallin was used in concentration $0.75 \mu \mathrm{g} / \mathrm{ml}$. Results of typical experiment out of 3 experiments performed are shown
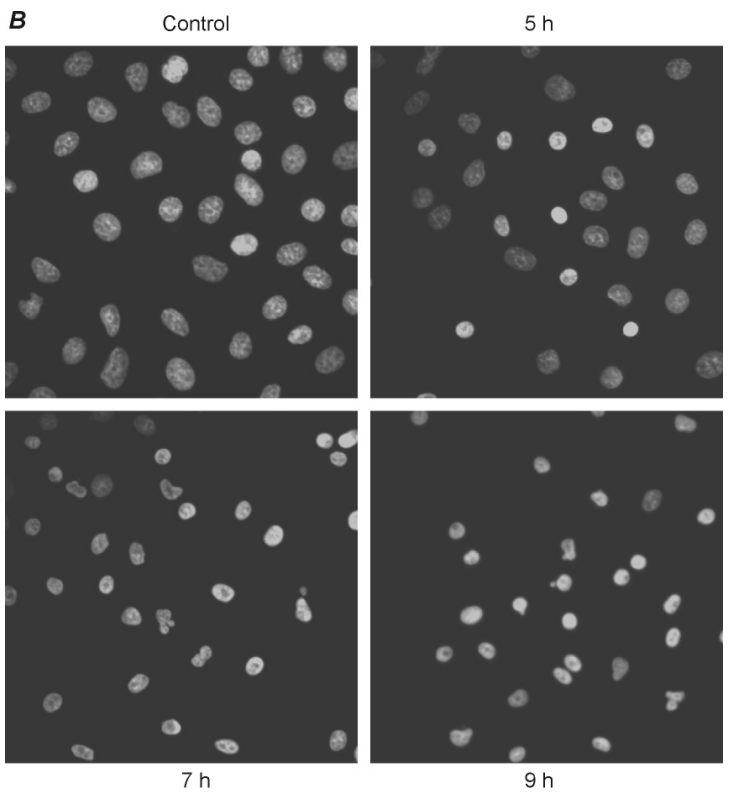

Time dependence of toxophallin effect was studied by using trypan blue exclusion test and DAPI staining. The results of that study demonstrated that toxophallin-induced cell death became noticeable after $5 \mathrm{~h}$ action (Fig. 6, $A$ ). Nuclei condensation detected by DAPI staining after $5 \mathrm{~h}$ treatment with toxophallin, was the earliest toxophallin effect (Fig. $6, B$ ) that was subsequently accompanied by apoptotic nuclei fragmentation observed in 7-9 h of toxophallin action towards target cells.

Concluding, a novel cytotoxic protein was isolated from the death cap and characterized in this study. According to its physico-chemical and biological characteristics, that protein does not correspond to any earlier described Amanita phalloides toxic substances, such as toxic cyclopeptides or phallolysin.

\section{DISCUSSION}

When studying toxic proteins isolated from fruit bodies of the death cap Amanita phalloides by using approaches of both biochemistry and cell biology, we detected a novel toxic protein differing from earlier described toxic protein (phallolysin) of that mushroom species. In the present study, an improved procedure for purification of that protein was developed and detailed investigation of its physico-chemical properties and biological activity was conducted.

It was found that this novel toxic protein differs distinctly from phallolysin which was isolated and characterized by Seeger et al. [16-18] and Faulstich et al. [4, 5]. Some of those characteristics are presented in Table 3.

Both proteins differ substantially in their biological activity. Phallolysin is highly toxic in animals reaching a lethal dose $40 \mu \mathrm{g} / \mathrm{kg}$ in rabbits [4]. In our in experiments based on using cultured L1210 cells, the cytotoxic dose $I_{50}$ equaled $5 \mu \mathrm{g} / \mathrm{ml}$. It was found that toxophallin exhibited high toxicity towards mammalian cells, for example, $I_{50}$ was equal $0.25 \mu \mathrm{g} / \mathrm{ml}$ in cells of L1210, A549, and T47D lines, and it was $0.45 \mu \mathrm{g} / \mathrm{ml}$ in cells of CCL-64 and MCF7 lines. No hemolytic activity was 
detected in toxophallin preparations, while the hemolytic activity of phallolysin achieved 24,000 units/mg [5].

It should be noted that toxophallin mRNA $(2.1 \mathrm{~kb})$ is expressed mainly in the stem and to a less extent in the cap of Amanita phalloides fruit bodies. No homologous toxophallin mRNA was found in fruit bodies of other species of Amanita genus such as Amanita rubescens or Amanita spissa, and in Phallus impudicus, as revealed by Northern-blot analysis using RT-PCR fragment of cloned toxophallin cDNA, as a probe for hybridization reaction (these our data are not presented in this paper). Those results suggest a non-ubiquitous expression of toxophallin in Amanita phalloides related mushroom species.

Table 3. Comparison of physico-chemical properties of toxophallin and phallolysin

\begin{tabular}{l|l|l}
\hline \multicolumn{1}{c|}{ Properties } & \multicolumn{1}{c}{ Toxophallin } & \multicolumn{1}{c}{ Phallolysin } \\
\hline Molecular mass & $57 \mathrm{kDa}$ & $34 \mathrm{kDa}$ \\
\hline $\mathrm{pl}$ & 5.7 & $7.0-8.1$ (three isoforms) \\
\hline $\begin{array}{l}\text { Characteristic features of } \\
\text { amino acid composition }\end{array}$ & $\begin{array}{l}\text { Rich in proline, also contains } \\
\text { cysteine and methionine }\end{array}$ & $\begin{array}{l}\text { Rich in serine, threonine, } \\
\text { glycine, and lysine, and lacks } \\
\text { cysteine and methionine }\end{array}$ \\
\hline
\end{tabular}

Cross-linking receptor study did not reveal specific receptor molecules for this protein on the surface of target cells. It was found that cytotoxic effects develop relatively slowly, since the first signs of cell damage were observed only in 6 hours of cell treatment. Target cells were undergoing apoptosis at toxophallin treatment, and cell death did not depend upon activation of caspase cascade. The most pronounced destructive changes were observed in the cell nucleus, namely condensation of nuclear chromatin and DNA fragmentation. These processes are characteristic for cell damage caused by ionizing radiation and they are mediated by generation of reactive oxygen species (ROS). Thus, it might be suggested that toxophallin induces cell damage indirectly via generation of free radicals and oxidant agents which can trigger cell damage and apoptosis by caspase-independent pathway.

\section{ACKNOWLEDGEMENTS}

This work has been supported by the grant awarded by the Royal Swedish Academy of Sciences. T.S. was also partially supported by the grant from the WestUkrainian BioMedical Research Center.

1. Овчинников Ю.А. Биоорганическая химия. Москва: Просвещение, 1987: 276-278. (Ovchinnikov Yu.A. Bioorganic Chemistry (in Russian), Moskow: Prosveshchenie, 1987: 276-278).

2. Antonyuk V.A. Method for obtaining affinity sorbent for purification of lectins. USSR Patent, N 1554961. Published in: Bull Isobret, 1990, N 13 (in Russian).

3. Borchers A.T., Stern J.S., Hackman R.M. et al. Mushrooms, tumors, and immunity. Proc. Soc. Exp. Biol. Med, 1999; 221(4): 281-293.

4. Faulstich H., Weckauf-Bloching M. Isolation and toxicity of two cytolytic glycoproteins from Amanita phalloides mushrooms. Hoppe Seylers Z Physiol. Chem, 1974; 355: 1489-1494. 
5. Faulstich H., Buhring H.-J., Seitz J. Physical properties and function of phallolysin. Biochemistry, 1983; 22: 4574-4580.

6. Franzŭn P., ten Dijke P., Ichijo H. et al. Cloning of a TGF beta type I receptor that forms a heteromeric complex with the TGF beta type II receptor. Cell, 1993; 75: 681-692.

7. Frolik C. A., Wakefield L. M., Smith D. M. and Sporn M. B. Characterization of a membrane receptor for transforming growth factor-beta in normal rat kidney fibroblasts. J. Biol. Chem, 1984; 259: 10995-11000.

8. Herrmann M., Lorenz H.-M., Voll R. et al. A rapid and simple method for the isolation of apoptotic DNA fragments. Nucl. Acid. Res, 1994; 22: 5506-5507.

9. Hobbs $C h$. Medicinal mushrooms: an exploration of tradition, healing, and culture. Botanica press: Summertown, Tennessee, 2003. 252 p.

10. Kretz O., Creppy E.E., Boulanger Y., Dirheimer G. Purification and some properties of bolesatine, a protein inhibiting in vitro protein synthesis, from the mushroom Boletus satanas Lenz (Boletaceae). Arch. Toxicol. Suppl, 1989; 13: 422-427.

11. Laemmli U.K. Cleavage of structural proteins during the assembly of the head of bacteriophage T 4. Nature, 1970; 277: 680-685.

12. Lutsik-Kordovsky M.D., Stasyk T.V., Stoika R.S. Analysis of cytotoxicity of lectin and nonlectin proteins from Amanita mushrooms. Exp. Oncol, 2001; 23(1): 43-45.

13. Mizuno T., Saito H., Nishitoba T., Kawagishi H. Antitumor-active substances from mushrooms. Food. Rev. Int, 1995; 11: 23-61.

14. Maurer H. R. Disc Electrophoresis and Related Techniques of Polyacrylamide Gel Electrophoresis. 2. Ed., W. de Gruyter, N. Y. 1971.

15. Parslew R., Jones K., Rhodes J.M., Sharpe G.R. The antiproliferative effect of lectin from edible mushroom Agaricus bisporus on human keratinocytes: preliminary studies of its use in psoriasis. Brit. J. Dermatol, 1999; 140: 56-60.

16. Seeger R., Scharrer H., Haupt M. Phallolysin, ein hochmolekulares Toxin aus Amanita phalloides. Experientia, 1973; 29: 829-830.

17. Seeger $R$. Demonstration and isolation of phallolysin, a haemolytic toxin from Amanita phalloides. Naunyn-Schmiedebergs Arch. Pharmacol, 1975; 287: 277-287.

18. Seeger R., Wachter B. Rubescenslysin and phallolysin release marker molecules from phospholipid cholesterol liposomes. Biochim. Biophys. Acta, 1981; 645: 59.

19. Souchelnytskyi S, ten Dijke P, Miyazono K, Heldin CH. Phosphorylation of Ser165 in TGFbeta type I receptor modulates TGF-beta1-induced cellular responses. EMBO J, 1996; 15(22): 6231-6240.

20. Wang H.X., Ng T.B., Liu W.K. et al. Isolation and characterization of two distinct lectins with antiproliferative activity from the cultured mycelium of the edible mushroom Tricholoma mongolicum. Int. J. Pept. Protein. Res, 1995; 46: 508-513.

21. Wieland $T$, Faulstich $H$. Amatoxins, phallotoxins, phallolysin, and antamanide: the biologically active components of poisonous Amanita mushrooms. CRC Crit. Rev. Biochem, 1978; 5(3): 185-260.

22. Yao Q.Z., Yu M.M., Ooi L.S. et al. Isolation and Characterization of a Type 1 RibosomeInactivating Protein from Fruiting Bodies of the Edible Mushroom (Volvariella volvacea). J. Agr. Food. Chem, 1998; 46(2): 788-792.

Одержано: 28.05.2008 